\title{
Identification, Characterization, and Expression Analyses of Class II and IV Chitinase Genes from Douglas-Fir Seedlings Infected by Phellinus sulphurascens
}

\author{
M. A. Islam, R. N. Sturrock, H. L. Williams, and A. K. M. Ekramoddoullah
}

Natural Resources Canada, Canadian Forest Service, Pacific Forestry Centre, 506 West Burnside Road, Victoria, BC, V8Z 1M5, Canada. Accepted for publication 14 December 2009.

\begin{abstract}
Islam, M. A., Sturrock, R. N., Williams, H. L., and Ekramoddoullah, A. K. M. 2010. Identification, characterization, and expression analyses of class II and IV chitinase genes from Douglas-fir seedlings infected by Phellinus sulphurascens. Phytopathology 100:356-366.

Laminated root rot (LRR) disease, caused by the fungus Phellinus sulphurascens, is a major threat to coastal Douglas-fir (DF) (Pseudotsuga menziesii) forests in western North America. Understanding host-pathogen interactions of this pathosystem is essential to manage this important conifer root disease. Our research objectives were to identify DF pathogenesis-related (PR) genes and analyze their expression patterns over the course of infection. We constructed a cDNA library of Phellinus sulphurascens-infected DF seedling roots and sequenced a total of 3,600 random cDNA clones from this library. One of the largest groups of

identified genes (203 cDNA clones) matched with chitinase genes reported in other plant species. We identified at least three class II and six class IV chitinase genes from DF seedlings. Quantitative reverse-transcriptase polymerase chain reaction analyses showed significant differential expression patterns locally in root tissues and systemically in needle tissues after fungal invasion. Nonetheless, there was a common trend in gene expression patterns for most of the chitinase genes: an upregulation within $12 \mathrm{~h}$ of pathogen inoculation followed by downregulation within 2 to 3 days postinoculation (dpi), and then further upregulation within 5 to 7 dpi. Western immunoblot data showed differential accumulation of class IV chitinases in Phellinus sulphurascensinfected DF seedlings. Further detailed functional analyses will help us to understand the specific role of DF chitinases in defense against Phellinus sulphurascens infection.
\end{abstract}

Plants undergo continuous exposure to a variety of biotic and abiotic stresses in their natural habitats. In response to these stresses, plants have evolved a complex mechanism to perceive external signals, allowing optimal response to different stresses (23). Phytohormones such as abscisic acid, ethylene, jasmonic acid, and salicylic acid primarily regulate the defensive responses. Through this hormonal signaling, plants activate a series of defense responses which include cell wall reinforcement and production of antimicrobial compounds and hydrolytic enzymes (8). These physiological processes are not only essential to combat pathogenic attacks but also essential to protect plants from other abiotic stresses $(17,23)$. The regulation of defenserelated genes is one of the key elements of the defense mechanism that is used by plants against biotic and abiotic agents (17), and results in the accumulation of host-encoded proteins $(38,60)$ termed pathogenesis-related (PR) proteins (66). These PR proteins have been grouped into 17 different families and classes based on similarities in amino acid sequence, serology, or enzymatic or biological activity $(13,66,67)$.

The chitinase family (EC 3.2.1.14) of PR proteins is of particular importance to fungal pathosystems because all true fungi

\section{Corresponding author: M. A. Islam; E-mail address: aislam@nrcan.gc.ca}

\footnotetext{
* The $\boldsymbol{e}$-Xtra logo stands for "electronic extra" and indicates that the online version contains three figures showing alignment of nucleotide sequences of DF class II and IV chitinase genes, a phylogenetic tree constructed according to nucleotide sequences for DF class II and IV chitinases and for an acidic chitinase from Picea sitchensis and a basic chitinase from Picia abies, and alignment of amino acid sequences for DF class II and IV chitinases from DF and other species. Figures 2 and 3 appear in color online.
}

doi:10.1094/PHYTO-100-4-0356

(C) 2010 Her Majesty the Queen in right of Canada, Natural Resources Canada, Canadian Forest Service contain chitin as a primary structural component of their cell wall (70). Chitin is a linear homopolymer of $N$-acetyl-D-glucosamine and it is hydrolyzed by chitinases into smaller oligomers or monomers $(5,70)$. In many pathosystems, chitinases are considered to play a major role during plant-fungus pathogenic interactions $(15,25,33,41,58)$. Chitinase coding genes have been shown to be overexpressed or chitinase activities enhanced during fungal $(16,65)$, bacterial (24), and viral (12) plant infection, as well as during symbiotic interactions with Rhizobium spp. (34) and mycorrhizal fungi $(22,29)$. Recently, this gene family has become a subject of interest to many scientists and professionals because it has substantial prospects for biocontrol $(35,51)$ and biofuel production (18).

In most plants, chitinases occur in diverse groups that differ in primary structure, isoelectric point $(\mathrm{p} I)$, and cellular localization $(15,41,60)$. The classification of plant chitinases has focused on the presence of auxiliary domains-namely, a chitin-binding domain, a hinge domain, and a carboxy-terminal extensionflanking the main catalytic domain (26). Based on these structural variations and sequence divergence, chitinases have been grouped into different classes (41). So far, seven classes (I to VII) of chitinases have been proposed and these seven classes fit into 3 of the 17 identified PR protein families $(9,33)$. The family PR-3 includes chitinases of class I, II, IV, VI, and VII; family PR-8 includes chitinases of class III; and family PR-11 includes chitinases of class V $(33,46)$. Additionally, in family PR-4, some proteins with low endochitinase activity were found (46).

The class II and IV chitinases belong to the glycosyl hydrolase family 19 and share a homologous catalytic domain (33). Among the plant chitinases, class II chitinases have only a catalytic domain homologous to that of class I chitinases, whereas class IV chitinases are composed of an $\mathrm{N}$-terminal chitin-binding domain, a hinge region, and a catalytic domain. Both class II and IV 
chitinases are secreted to the apoplast (25) and they do not show homology with class III and V chitinases $(3,33)$. Although class II and IV chitinases show homology with class I chitinases, they differ in several ways: (i) the chitin-binding domain of class IV has cysteines at seven of eight positions in common with class I chitinases, but the reminder of their sequences vary greatly, while class II lacks this domain; (ii) there are four deletions in class IV chitinases, one within the chitin-binding domain and three within the catalytic domain-this shortens the final protein product compared to class I chitinases; and (iii) a C-terminal extension found in most class I chitinases is missing in both class II and IV chitinases (25). The evolution of diverse chitinase families within a plant species leads to this question about the specificity of their function: why do plants need so many diversified enzymes to hydrolyze polymers of $\mathrm{N}$-acetyl-D-glucosamine?

In western North America, the fungal pathogen Phellinus sulphurascens Pilát (syn. Phellinus weirii (Murrill) R. L. Gilbertson) causes laminated root rot (LRR), a disease that affects the growth and survival of Douglas-fir (DF) (Pseudotsuga menziesii (Mirb.) Franco.) and other conifers $(37,45,63)$. Productivity in forested stands, especially those dominated by DF, can be significantly reduced wherever this pathogen occurs $(6,63)$. To better understand this pathosystem, we have been conducting research with Phellinus sulphurascens-infected DF seedlings under a laboratory setup to document the infection process $(32,61)$ and to identify defense related proteins (31) and genes (unpublished data). In this article, we report nine chitinase genes from a DF cDNA library and investigate their differential expression in DF seedlings infected by Phellinus sulphurascens over 7 days using quantitative reverse-transcriptase polymerase chain reaction (qRT-PCR). We also document accumulation of a class IV chitinase protein in roots and needles of DF seedlings using an antibody that was originally developed against a western white pine (Pinus monticola Dougl. ex D. Don) class IV chitinase (40).

\section{MATERIALS AND METHODS}

Fungal and plant materials and inoculation technique. The isolate PFC-581 of Phellinus sulphurascens was originally collected from the infected stem of a mature DF tree growing near Cowichan Lake on Vancouver Island, British Columbia (BC), Canada and used to infect DF seedlings in this study. The fungus was initially isolated from infected DF tissue onto petri plates containing 1.5\% malt extract agar (Sigma-Aldrich Canada Ltd., Oakville, ON, Canada). Plugs taken from these Phellinus sulphurascens cultures were maintained in cryovials with doubledistilled water $\left(\mathrm{ddH}_{2} \mathrm{O}\right)$ at $3^{\circ} \mathrm{C}$. These fungal plugs were further used to inoculate plates containing $1 \%$ (wt/vol) water agar (Sigma-Aldrich Canada Ltd.) which were incubated for $\approx 20$ days at room temperature and subsequently used to provide Phellinus sulphurascens inoculum for our experiments. Additional cultures of isolate PFC-581 were preserved in sterile distilled water in cryovials (11) and a fruiting body of the isolate was preserved as a herbarium specimen (DAVFP29265) and maintained at the Pacific Forestry Centre (PFC), Victoria, BC, Canada.

Seed from coastal DF family 60686 were obtained from the Tree Seed Centre of the British Columbia Ministry of Forests and Range, located in Surrey, BC, Canada. After soaking in $\mathrm{ddH}_{2} \mathrm{O}$ for $24 \mathrm{~h}$, seeds were stratified at $4^{\circ} \mathrm{C}$ for $\approx 21$ days, then surface sterilized in $35 \%$ aqueous $\mathrm{H}_{2} \mathrm{O}_{2}$ ( $\mathrm{vol} / \mathrm{vol}$ ) for 10 to 12 min with vigorous agitation, and finally rinsed at least four times with sterile $\mathrm{H}_{2} \mathrm{O}$. Sterilized seeds were then placed in petri plates (20 to 25 seeds per plate) containing $1 \%$ (wt/vol) water agar and allowed to germinate in darkness at $24 \pm 1^{\circ} \mathrm{C}$. Then, 14- to 20-day-old seedlings were aseptically transferred to bipartitioned petri plates and inoculated with Phellinus sulphurascens mycelia. One-half of each plate contained $1 \%$ (wt/vol) water agar containing Phellinus sulphurascens inoculum and the other half was kept empty. The roots rested on the water agar portion and their foliage rested in the empty portion. A second half agar block of Phellinus sulphurascens inoculum was placed upside down over the roots of all seedlings in each plate to make a sandwich, which ensured that all roots were in contact with fungal mycelia. The control seedlings received agar blocks without Phellinus sulphurascens mycelia. Petri plates were sealed with paraffin film and the halves containing treated roots were covered by aluminum foil and incubated in a growth chamber at $20^{\circ} \mathrm{C}$ with a photoperiod of $16 \mathrm{~h}\left(50\right.$ to $\left.60 \mu \mathrm{mol} \mathrm{m} \mathrm{m}^{-2} \mathrm{~s}^{-1}\right)$.

Construction of cDNA library from roots of Phellinus sulphurascens-infected DF seedlings. Total RNA was extracted from roots of Phellinus sulphurascens-infected DF seedlings using the protocol of Schultz et al. (56). Three independent RNA extractions sampled at 3,5 , and 7 days postinoculation (dpi) were pooled together to construct a cDNA library using the Creator SMART cDNA library construction kit (Clontech Laboratories, Inc., Mountain View, CA). Total RNA ( $\approx 100 \mathrm{ng})$ was used for cDNA synthesis following the instructions of the manufacturer. Recombinant pDNR-LIB plasmids containing our cDNAs were transformed into Escherichia coli (ElectroMAX DH10B electrocompetent cells; Invitrogen, Carlsbad, CA) following the manufacturer's instructions. To evaluate the quality of the full-length cDNA library, 50 individual cDNA clones were randomly picked from plates and screened using the M13 primers provided by the Creator SMART cDNA library construction kit to determine the percentage of recombinant clones. The library titer was calculated following Clontech's instruction manual.

Sequencing of cDNA clones and bioinformatics. The glycerol stock of the cDNA library was sent to the BC Cancer Agency in Vancouver, British Columbia for sequencing of 3,600 random clones. These cDNA sequences were analyzed using Sequencher software (version 4.8; Gene Codes Corporation, Ann Arbor, MI). Each sequence was edited by removing the vector sequence and ambiguous base pairs. Overlapping sequences (from both $3^{\prime}$ and $5^{\prime}$ ends) were evaluated and aligned into full consensus sequence contigs using the software, while non-overlapping sequences were formatted and treated as two separate sequence contigs. Consensus sequences were searched against the National Center for Biotechnology Information (NCBI) Basic Local Alignment Search Tool (BLASTx) (available online from NCBI) algorithm.

Identified chitinase gene sequences were aligned using online software ClustalW 1.83 (http://www.ebi.ac.uk/Tools/clustalw/ index.html). The alignment file was reviewed and adjusted manually where necessary to improve the alignment. Based on Sequencher and alignment data, nine distinct ( $\leq 98 \%$ nucleotide sequence identity) chitinase genes were identified from the DF chitinase cDNA database. The Expert Protein Analysis System (ExPASy) (http://us.expasy.org) proteomics server of the Swiss Institute of Bioinformatics was used to translate putative protein sequences from cDNAs and to determine molecular weight and $\mathrm{p} I$ values. Signal peptidase sites were predicted using the online version of SignalP 3.0 (http://www.cbs.dtu.dk/services/SignalP).

Using nucleotide sequence data of class II and class IV chitinase genes, a phylogenetic tree was constructed using the maximum parsimony bootstrapping method of Molecular Evolutionary Genetics Analysis (MEGA) version 4.0 (62). We included one gene encoding an acidic conifer chitinase (Picea sitchensis (Bong.) Carr.; PsitEF083194; accession no EF083194) and a gene encoding a basic conifer chitinase (Picea abies (L.) H. Karst.; PabiPA2AY270019; accession no. AY270019) to assess the sequence similarity of the DF chitinase genes that we identified with those of other conifers. To examine the evolutionary relationships between DF class II and class IV chitinases and these same classes in other plant taxa, a phylogenetic tree was constructed using the deduced amino acid sequences of the identified DF chitinases and sequence information for (i) the acidic and basic chitinases from Picea sitchensis and Picea abies previously 
mentioned and (ii) two acidic dicot chitinases (Arabidopsis thaliana (L.) Heynh.: AtalY14590; accession no. Y14590; and Vitis vinifera L.: VvenAF532966; accession no. AF532966), a basic dicot chitinase (Chenopodium amaranticolor Coste \& Reyn.: CamaBAA22968; accession no. BAA22968), and a basic monocot chitinase (Zea mays L.: ZmayACJ61914; accession no. ACJ61914) using the above-mentioned software.

Genomic DNA extraction and amplification. DF genomic DNA was extracted using the PowerPlant DNA Isolation Kit (MO BIO Laboratories, Inc., Carlsbad, CA). The genomic DNA was amplified using a class IV gene-specific primer pair (forward, TGCTGGGCGTAAGTGTTAATG and reverse, TTTGGCAGC AACAGAGAGAGA) by following the protocol of long-range PCR (Clontech). The PCR products were purified from $1.1 \%$ agarose gel using the QIAquick Gel Extraction Kit (Qiagen Inc., Valencia, CA) and then ligated to the pGEM-T Easy Vector (Promega Corp., Madison, WI) for sequencing. Genomic sequencing was performed at MACROGEN (Seoul, Korea) and sequences were analyzed and compared with DF chitinase cDNAs to identify introns in the DF genomic DNA.

cDNA synthesis and qRT-PCR. In total, 72 RNA samples were extracted from roots and needles of control and Phellinus sulphurascens-infected DF seedlings over six time points: 12 and $24 \mathrm{~h}$ and 2, 3, 5, and 7 days. Three independent biological replicates were sampled in triplicate from each time point. Each individual extraction included $\approx 10$ seedlings for $\approx 100 \mathrm{mg}$ of plant tissue from both roots and needles. The RNAqueous kit (Ambion, Austin, TX) was used to extract total RNA. The extracted RNA samples were treated with the TURBO DNase (Ambion), and the SUPERase In RNase Inhibitor (Ambion) was added to the recovered RNA. Total RNA was quantified using the Quant-iT RiboGreen RNA Reagent and kit (Invitrogen) as well as with the NanoDrop 1000 spectrophotometer (Thermo Scientific, Wilmington, DE).

First-strand cDNA was synthesized from $500 \mathrm{ng}$ of total RNA using the Transcriptor First-Strand cDNA Synthesis Kit (Roche Applied Science, Mannheim, Germany) following the manufacturer's instruction. Subsequently, the qRT-PCR was conducted with the synthesized cDNA using the LightCycler 2.0 System (Roche) according to the manufacturer's instructions. PCR products were obtained using primers specific for nine selected genes with a concentration of $500 \mathrm{nM}$ (Table 1). Two microliters of $100 \times$ diluted cDNA samples were used as the template for each reaction. PCR cycling parameters were $95^{\circ} \mathrm{C}$ for $10 \mathrm{~min}$; followed by 45 cycles of $95^{\circ} \mathrm{C}$ for $15 \mathrm{~s}, 60^{\circ} \mathrm{C}$ for $10 \mathrm{~s}$, and $72^{\circ} \mathrm{C}$ for $10 \mathrm{~s}$; one cycle of $95^{\circ} \mathrm{C}$ for melting curve; and, finally, $40^{\circ} \mathrm{C}$ for cooling. Fluorescent PCR products were generated from cDNA using the LightCycler FastStart DNA MasterPLUS SYBR Green I kit (Roche).

To analyze the expression of nine DF chitinase genes, primer pairs were designed for these genes using Roche's LightCycler Probe Design Software 2.0 (version 1.0; Roche) to amplify each of the nine genes for expression analysis (Table 1). We also designed primer pairs for three candidate reference genes- $\mathrm{Pm}$ Tubl (DF $\alpha$-tubulin), Pm Ucel (DF-ubiquitin conjugating enzyme), and Pm Tefl (DF-translation elongation factor $1 \alpha$ ) - and analyzed their expression patterns to find a suitable internal reference gene. Pm Tubl expression levels showed no significant variation between control and Phellinus sulphurascens-infected DF samples over time $(P<0.18)$, whereas $P m$ Uce 1 and $P m$ Tefl showed comparatively higher variation between treatments $(P<$ 0.07 and 0.05 , respectively). Thus, relative quantification of nine chitinase genes was analyzed using $P m$ Tubl as an internal reference gene, and was corrected using the PCR efficiency of each primer set. To determine the amplification efficiencies for the chitinase genes and the Pm Tubl gene, a concentrated cDNA sample was serially diluted over a 4-log range to cover the threshold cycles $(\mathrm{Ct})$ observed in the experimental (diluted) samples. qRT-PCR was performed for these dilutions and the $\mathrm{Ct}$ values were recorded at threshold and baseline parameters standardized for each of the transcripts. The data were plotted against the log of starting template concentration. The slope curve of the $\mathrm{Ct}$ cycles is dependent upon amplification efficiency $(E)$ calculated by the equation $E=10^{[-1 / \text { slope }]}$ (48). The expression level (R) of each chitinase gene of interest in relation to Pm Tubl in control

TABLE 1. Quantitative reverse-transcriptase polymerase chain reaction primers for selected Douglas-fir (DF) class II and IV chitinase genes and three internal reference genes ${ }^{\mathrm{a}}$

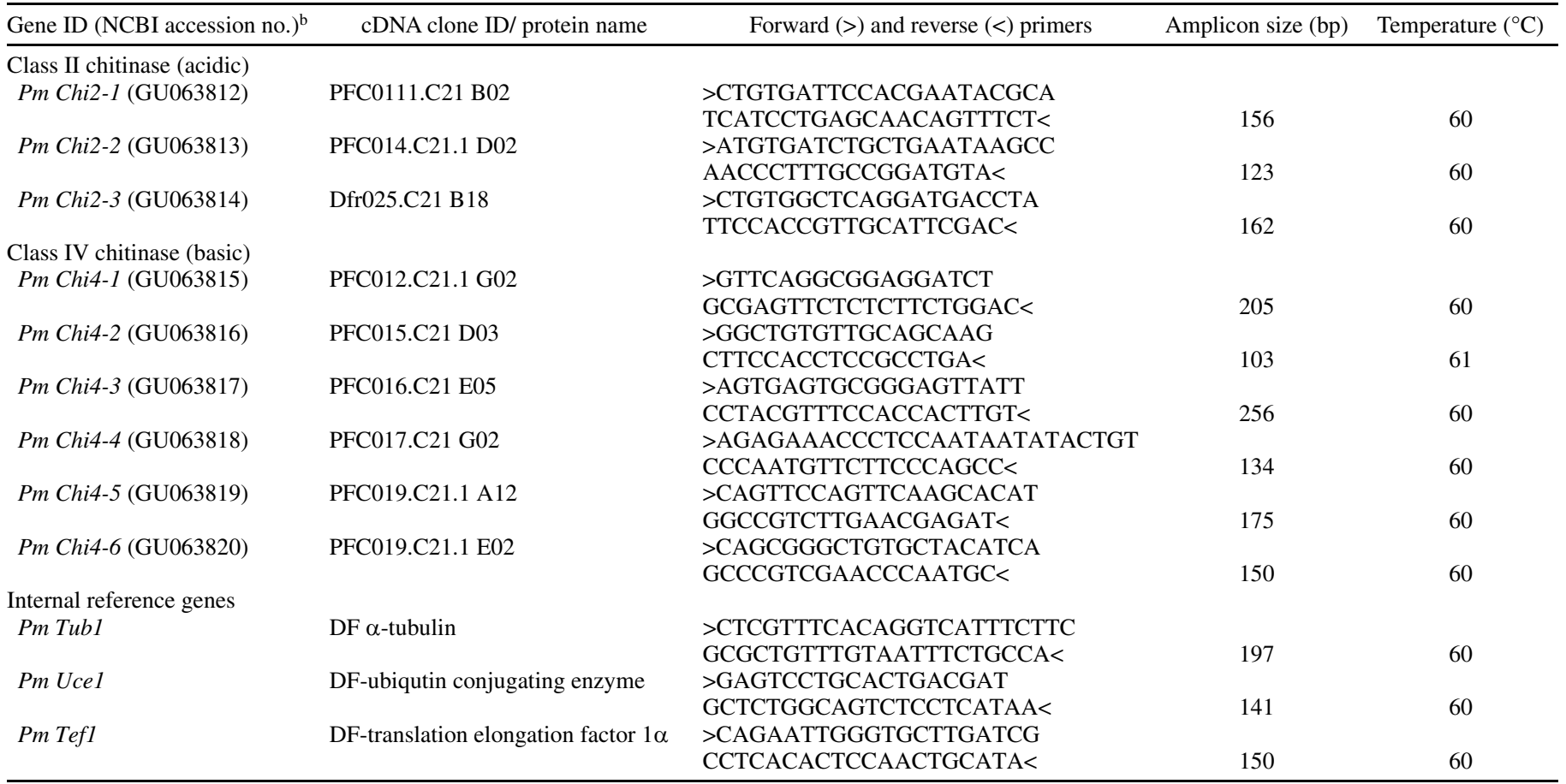

a Given cDNA clone IDs are created by the BC Cancer Agency Genome Centre during sequencing.

${ }^{\mathrm{b}} \mathrm{NCBI}=$ National Center for Biotechnology Information. 
and infected samples was calculated from the $\mathrm{Ct}$ values and PCR amplification efficiencies using the following equation (48): $R=\left[\left(E_{\text {target }}\right)^{\Delta \text { Cptarget(control - sample) }}\right] /\left[\left(E_{\text {ref }}\right)^{\Delta \text { Cpref(control - sample) }}\right]$.

To analyze and compare expression profiles for our two treatments (control versus infected) at different time points, transcript levels for control samples at $12 \mathrm{~h}$ were considered to be the basal levels during expression analysis and the corresponding transcript levels were given the value of 1.00 . Ct values for all control and infected transcripts were calculated based on this basal value. For each of the nine chitinase genes as well as the internal reference gene, three separate biological replicates were each amplified in triplicate.

Protein extraction. Root and needle tissue at $\approx 200 \mathrm{mg}$ (fresh weight) per sample was collected from Phellinus sulphurascensinfected seedlings at 3,5, and $7 \mathrm{dpi}$. Control samples treated with agar blocks only were collected at the same times. Samples were immediately frozen in liquid nitrogen and stored at $-80^{\circ} \mathrm{C}$. Protein extraction and determination of protein concentrations in all root and needle samples were performed according to the protocol of Ekramoddoullah and Davidson (19) with minor modifications. Briefly, frozen tissues were ground to powder in liquid nitrogen with a homogenizer (Retsch, Type MM2; Brinkmann Instruments Co., Toronto, ON, Canada) and extracted with $1 \mathrm{ml}$ of extraction solution ES1 [4\% sodium dodecyl sulfate [SDS], 5\% 2-mercaptoethanol, and $4 \%$ sucrose]. Protein was precipitated from the extraction buffer with acetone and collected by centrifugation for $30 \mathrm{~min}$ at 14,000 (Sigma-Aldrich Canada Ltd., 1-15 microcentrifuge; Montreal Biotech Inc., Dorval, Canada). Resulting protein pellets were each resuspended in $100 \mu \mathrm{l}$ of ES2 [ES1 supplemented with a $1 \%$ aqueous solution of NP-40 (nonyl phenoxylpolyethoxylethanol-40), Sigma 1-15 microcentrifuge and stored at $-20^{\circ} \mathrm{C}$ until used.

Western hybridization. An equal amount of total protein $(50 \mathrm{mg})$ from roots and needles of control and Phellinus sulphurascens-infected samples was loaded in 12 to $20 \%$ gradient SDS-polyacrylamide gel (Bio-Rad Laboratories, Mississauga, ON, Canada) electrophoresis. To calibrate the gels, a western white pine (WWP) class IV chitinase total protein sample known to contain the target protein was applied to all gels. Separated proteins were electrophoretically transferred to a polyvinylidene fluoride membrane (Millipore Corp., Bedford, MA) and probed with a polyclonal antibody originally developed against a WWP class IV chitinase (40). This primary polyclonal antibody was developed against synthetic, short-chain antigenic peptides of a WWP class IV chitinase protein, and the antibody was purified using an affinity column containing an immunosorbent prepared with the specific synthetic peptide and checked for specificity by enzyme-linked immunosorbent assay. Preparation and confirmation details of the antibody can be found in the work of Liu et al. (40). We used this antibody because the antigenic region (CASGKSYHGRGPLQLS) of this WWP class IV chitinase antibody is identical to that of DF class IV chitinases.

Developed membranes were then scanned using a GS-800 computer-interfaced imaging densitometer (Bio-Rad Laboratories) and protein quantification was done according to the instruction manual for Quantity One software (version 4.4; BioRad Laboratories). The optical density (OD) of all pixels within the boundary of all visible bands was measured based on internal calibration standards specific to the scanner. The resulting values of relative amounts of protein were reported in OD multiplied by bandwidth in millimeters $(\mathrm{OD} \times \mathrm{mm})$. To confirm the reproducibility of results, Western blot experiments were repeated at least three times with three biological replicates.

Statistical analysis. Gene expression data were analyzed by using the repeated measures analysis of variance method using the PROC GLM of SAS (version 9.1; SAS Institute Inc. Cary, NC). Least square mean (LSmean) differences (95\% confidence interval) in gene expression ( $\mathrm{Ct}$ values) between control and
Phellinus sulphurascens-infected DF at the various time points were analyzed at $5 \%$ level of significance (i.e., $\alpha=0.05$ ). Gene expression was calculated as a ratio of the LSMean of the control group to the LSMean of the Phellinus sulphurascens-infected DF group at a given time point. Expression profile graphs were generated using PROC GPLOT of SAS. Protein quantification data were also analyzed using PROC GLM-analysis of covariance with Tukey tests using the same software.

\section{RESULTS}

Isolation and characterization of DF class II and IV chitinase genes. Using the BLASTx algorithm, we identified 203 cDNA clones to be putative DF chitinase genes that matched significantly with chitinase genes in other plants. Of these DF cDNA clones, 54 were identified as class II and 149 as class IV. These cDNA clones were obtained from random sequencing of 3,600 clones from a cDNA library we created from roots of Phellinus sulphurascens-infected DF seedlings. Further bioinformatic analyses of DF chitinase cDNAs confirmed that DF seedlings contained at least nine genes (Table 1). We obtained full-length open reading frames (ORFs) for all these genes except for $\mathrm{Pm}$ Chi4-3. These full-length ORFs were 523 to $834 \mathrm{bp}$ (e-Xtra) and encoded mature proteins with 170 to 278 amino acid residues. We did not include $\mathrm{Pm} \mathrm{Chi4-3}$ in sequence characterization because we did not obtain a full-length sequence of this gene. We found at least two distinct classes of chitinases in DF plants: classes II and IV. Interestingly, all our DF chitinases with acidic $\mathrm{p} I$ values were identified as class II chitinases and all those with basic $\mathrm{p} I$ values were identified as class IV chitinases. Alignment of the chitinase genes showed considerable sequence variation between the two classes and, to a lesser extent, within the two classes. Within the class II chitinase genes, the nucleotide sequence identity was 73 to $92 \%$, whereas class IV chitinase genes shared 88 to $99 \%$ identity. Sequence identity between class II and class IV DF chitinase genes was 38 to $55 \%$. There was 82 to $83 \%$ sequence identity between class II DF chitinase genes and the Picea sitchensis chitinase gene and 86 to $87 \%$ between class IV DF chitinase genes and the chitinase gene of Picea abies. We also found that identified DF class II and class IV chitinase genes contain two AT-rich introns. These intron positions are shown in the online $e$-Xtra. Using a selection of DF class II and class IV genes and two additional conifer genes, we constructed a phylogenetic tree that showed relationships of two distinct classes of DF class II and class IV chitinase genes (e-Xtra).

To further elucidate relationships between chitinases within and between species, we used ClustalW to align the putative amino acid sequences of DF class II and class IV chitinases, two acidic dicot chitinases (A. thaliana and $V$. vinifera), a basic dicot chitinase (C. amaranticolor), a basic monocot chitinase (Z. mays), and the same acidic and basic conifer chitinases included in the alignment data ( $e$-Xtra). The DF class II chitinases shared 66 to $86 \%$ sequence identity while the DF class IV chitinases shared 84 to $95 \%$ identity. Between these two classes, the sequence identity was 41 to $55 \%$. DF class II chitinases shared 77 to $78 \%$ identity with the acidic chitinase of Picea sitchensis, whereas DF class IV chitinases shared 82 to $83 \%$ identity with the Picea abies chitinase. Between DF class II and dicot acidic chitinases, the identity was 46 to $55 \%$. DF class IV chitinases also shared 46 to $55 \%$ sequence identity with dicot basic chitinases. The predicted molecular masses of class II chitinases ranged from 21.85 to $22.59 \mathrm{kDa}$ and for class II chitinases ranged from 25.11 to 25.78 $\mathrm{kDa}$. The $\mathrm{p} I$ values for class II and class IV chitinases, respectively, ranged from 4.24 to 4.76 and 7.91 to 8.66 .

Comparison of the deduced DF chitinases with those characterized from other plant species revealed a $\mathrm{C}$-terminal catalytic domain that has considerable sequence similarity to the catalytic domain of plant class I, II, and IV chitinases belonging to the 
glycosyl hydrolase family 19. We identified class II and class IV chitinases from DF based on the presence or absence of an $\mathrm{N}$ terminal cysteine-rich chitin-binding domain, a glycine-rich hinge domain, and a C-terminal extension, as well as sequence homology of the C-terminal catalytic domain. A chitin-binding domain signature PS00026 (1) was localized in DF class IV chitinases

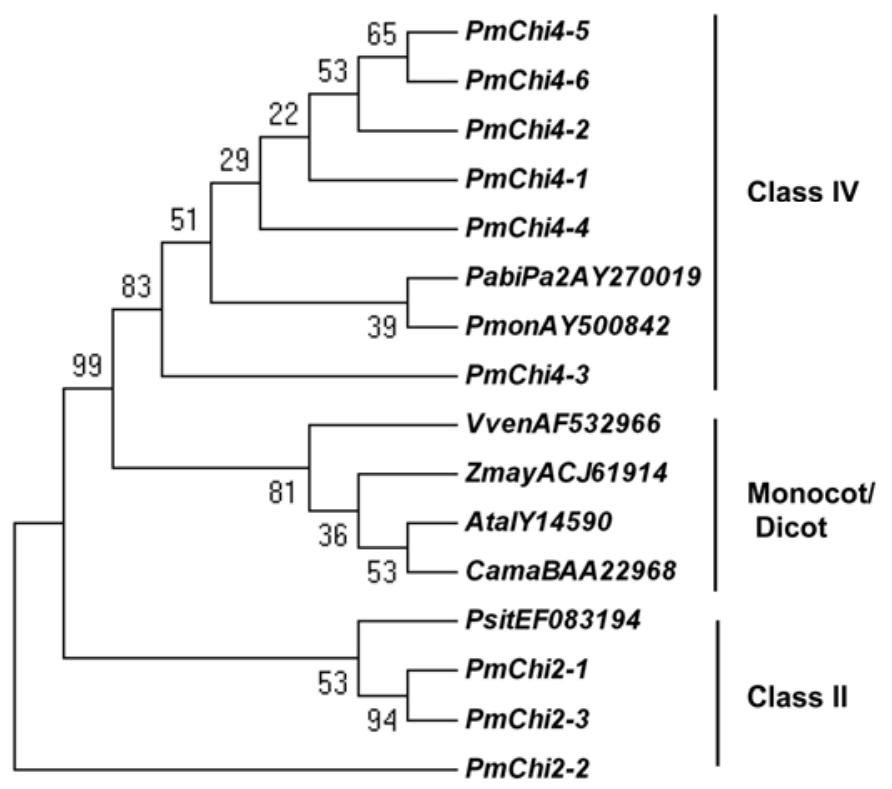

Fig. 1. Phylogenetic tree constructed using deduced amino acid sequences from Douglas-fir class II and IV chitinases along with one acidic and one basic conifer chitinase (Picea sitchensis: PsitEF083194 and P. abies: PabiPA2AY270019, respectively), two acidic dicot chitinases (Arabidopsis thaliana: AtalYY14590 and Vitis vinifera: VvenAF532966), one basic dicot chitinase (Chenopodium amaranticolor: CamaBAA22968), and one basic monocot chitinase (Zea mays: ZmayACJ61914). from position Cys-31-32 to Cys-50-51 (e-Xtra). A conserved motif (N-Y/F-NYG) was present in both class II and class IV chitinases just two amino acids after the antigenic region ( $e$-Xtra). This region is essential for hydrolytic activity (68). A potential Nlinked glycosylation site $(\mathrm{N}-\mathrm{X}-\mathrm{S})$ was present at the C-terminal end. We constructed a phylogenetic tree which clearly separated all the chitinases we compared into three major groups: class II, class IV, and the chitinases of dicotyledonous and monocotyledonous plants. The two conifer species grouped with DF chitinases according to their $\mathrm{p} I$ characteristics. The acidic and basic chitinases from the monocot and dicot plants showed comparatively higher sequence similarity than conifers, and grouped together in a distinct clade which separated the acidic and basic conifer chitinases (Fig. 1).

Expression of DF class II and IV chitinase genes. We performed qRT-PCR gene expression analyses for three class II and six class IV chitinase genes from DF seedlings. Expression profiles for both classes showed significant changes in transcript levels following fungal infection, both locally in root tissues and systemically in needle tissues (Figs. 2 and 3). A significant upregulation was observed in expression for both classes of DF chitinase genes. In general, there was an increase after pathogen inoculation at $12 \mathrm{~h}$ postinoculation (hpi) and 2 dpi followed by a significant decrease within 3 to $5 \mathrm{dpi}$ and then a further significant increase within 5 to $7 \mathrm{dpi}$.

For both chitinase classes, local responses in roots were comparatively sooner than systemic responses in the needles. Some chitinases were significantly upregulated in the roots within 12 hpi (Figs. 2 and 3; Table 2). For example, the DF class II chitinases Pm Chi2_2 (3.70-fold, $P=0.01$ ) and Pm Chi2_3 (5.70fold, $P=0.00)$ and the class IV chitinases $P m$ Chi4_l 1 (7.20-fold, $P=0.01)$ and $P m$ Chi4_4 (17.40-fold, $P=0.02)$ all showed significant increases in transcript levels at 12 hpi. Among all the chitinases, Pm Chi4_3 showed the highest increase at 12 hpi (31.30-fold). However, in most of the cases, the highest level of expression was observed at $7 \mathrm{dpi}$.
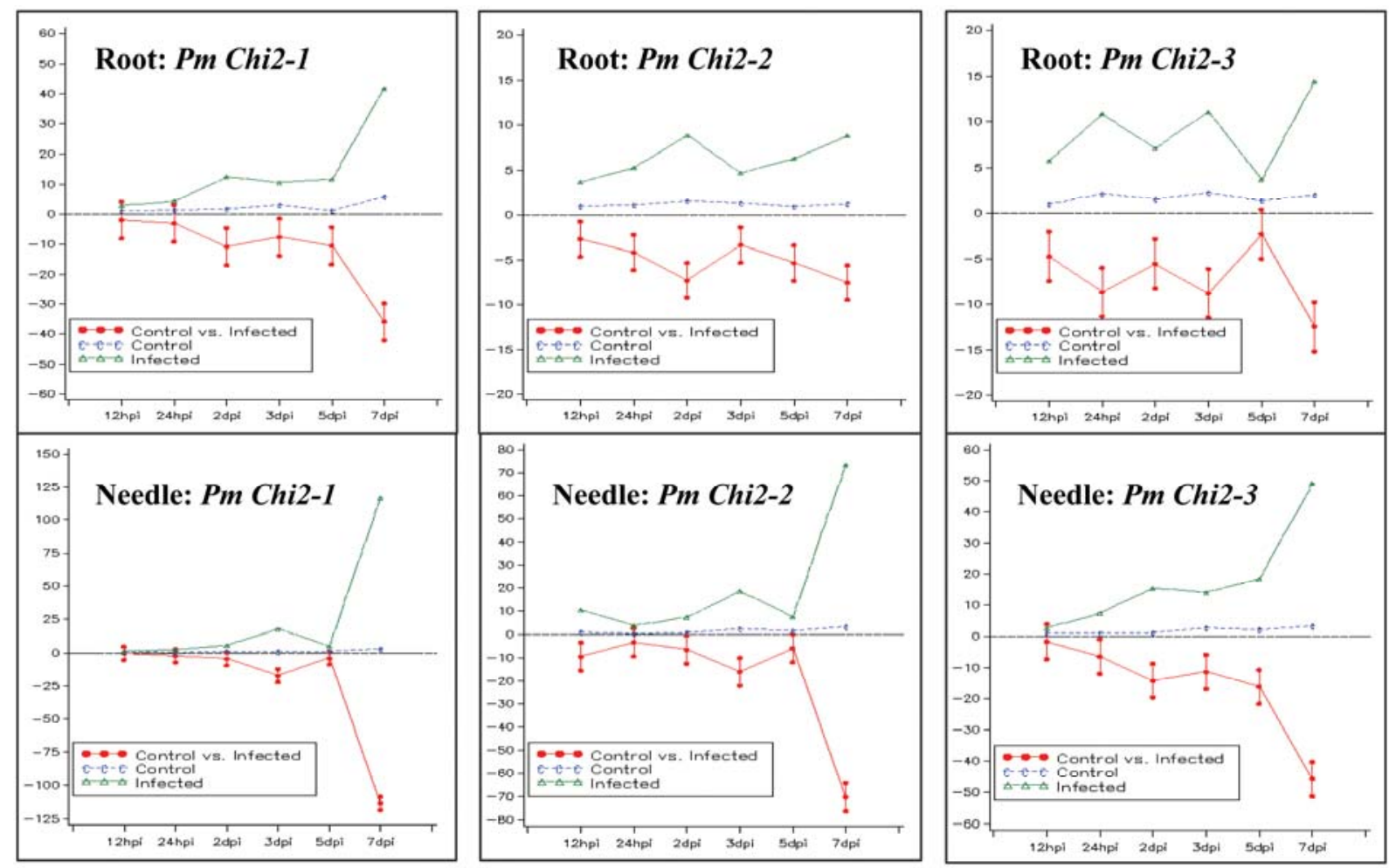

Fig. 2. Relative gene expression profiles for class II chitinase genes over 7 days in control and Phellinus sulphurascens-infected Douglas-fir (DF) seedlings. Quantitative reverse-transcriptase polymerase chain reaction data analysis was based on comparative crossing threshold values of the amplicons (Y-axis) over the time course (X-axis). DF $\alpha$-tubulin (Pm Tubl) was used as an internal reference gene. Tissue types and the gene names are shown above the corresponding graphs. 
In most of the needle tissues, chitinase transcript levels did not show any significant increase at $12 \mathrm{hpi}$ or 24 dpi. Only the class II chitinase Pm Chi2_2 showed a significant increase after pathogen challenge at 12 hpi $(10.40$-fold, $P=0.01)$. In most cases, the first expression peak in the needles was recorded within 2 to $3 \mathrm{dpi}$. Our results revealed that upregulation of DF class II chitinases was comparatively higher in needles of infected DF seedlings. In contrast, the upregulation of class IV chitinases was higher in root tissues (Table 2). Additionally, gene expression of class II chitinases was slower than that of the class IV chitinases. Overall, the highest average fold change occurred in needles at 7 dpi for the class IV chitinases and at only 24 hpi for the basic chitinases in root samples (Fig. 4).

Western hybridization data. The antigenic region of the WWP antibody that we used is identical to the antigenic region (CASGKSYHGRGPLQLS) of DF class IV chitinases and $\approx 90 \%$ identical to the class II chitinases. Therefore, we expected the Western immunoblot protein detection to produce a cumulative signal of a number of DF chitinases. Western immunoblot data showed significant changes in the accumulation of chitinases
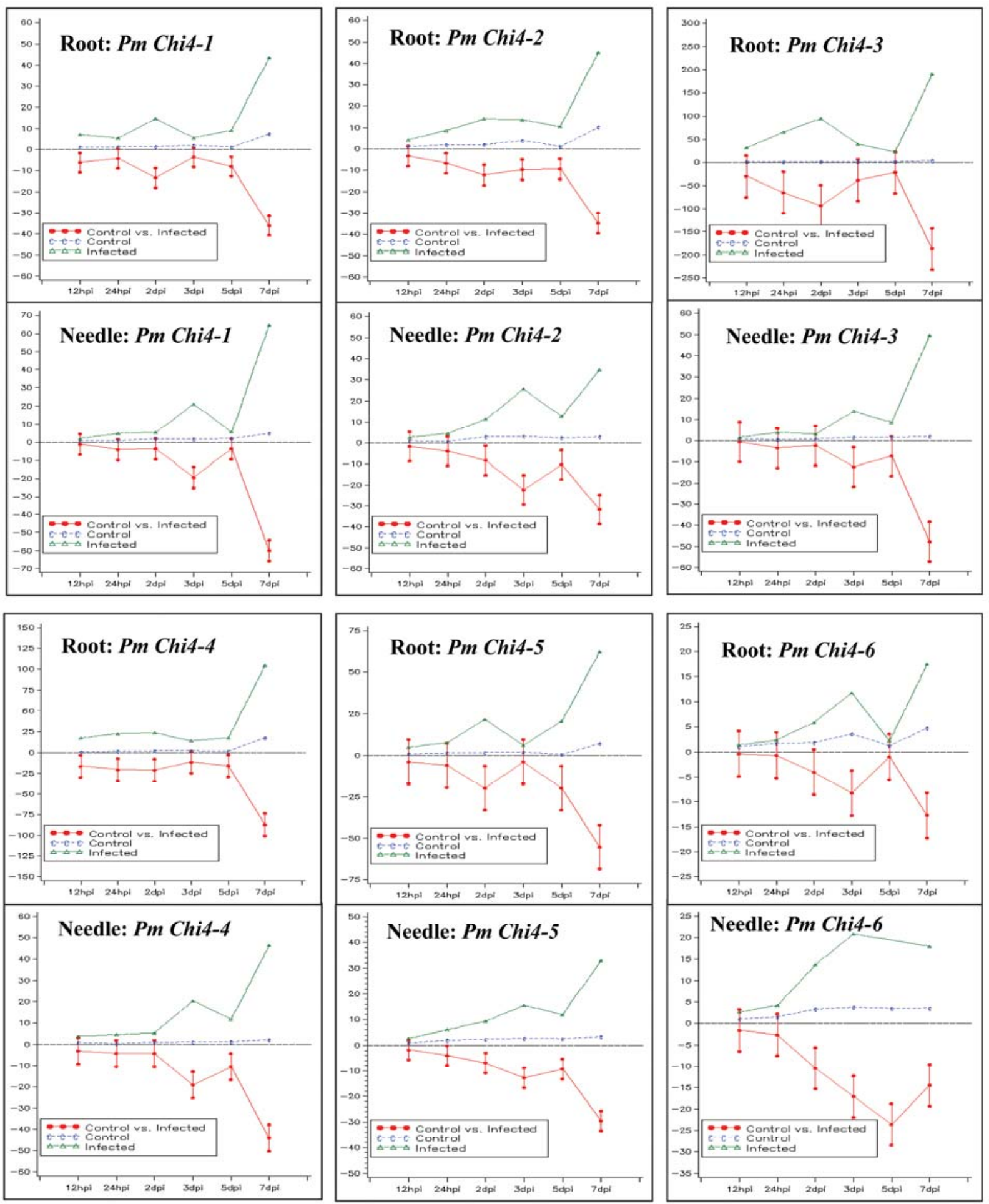

Fig. 3. Relative gene expression profiles for class IV chitinase genes over 7 days in Douglas-fir (DF) seedlings infected with Phellinus sulphurascens. Quantitative reverse-transcriptase polymerase chain reaction data analysis was based on comparative crossing threshold values of the amplicons (Y-axis) over the time course (X-axis). DF $\alpha$-tubulin (Pm Tub1) was used as an internal reference gene. Tissue types and the gene names are shown above the corresponding graphs. 
between control and Phellinus sulphurascens-infected DF seedlings. We found that chitinases were constitutively expressed in $\mathrm{DF}$ root and needle tissues, although protein accumulation in control samples was very low (Fig. 5A to D). Accumulations of DF chitinases markedly increased in roots and needles of Phellinus sulphurascens-infected seedlings, especially at $7 \mathrm{dpi}$. In roots, the OD at $7 \mathrm{dpi}$ was $3.41( \pm 0.53), 3.28 \times$ higher than in the control (Fig. 5A and B) whereas, in needle tissue at $7 \mathrm{dpi}$, the OD value was $2.47( \pm 0.44), 8.82 \times$ higher than the control tissue (Fig. $5 \mathrm{C}$ and $\mathrm{D})$. At $3 \mathrm{dpi}$, there were no significant changes between control and infected samples for both root $(P=0.17)$ and needle $(P=0.06)$ tissues whereas, at 5 and $7 \mathrm{dpi}$, significant upregulation in both root $(P=0.01)$ and needle $(P=0.01)$ tissues was observed.

\section{DISCUSSION}

To better understand laminated root rot and the molecular interaction between DF and Phellinus sulphurascens, one of our major research interests is the identification of genes that are involved in DF defense mechanisms. Thus, we have constructed a cDNA library and identified a large number of PR genes from DF roots infected by Phellinus sulphurascens (M. A. Islam, unpublished data). These data have enabled us to conduct further gene expression studies on DF defense-related genes. In this study, we focused on DF chitinase genes because this was the largest defense-related gene family we found in our cDNA library and because the mode of action of chitinases suggest that they are important to the DF defense system. Also, very few studies have been conducted on conifer chitinase genes and, to our knowledge, this is the first description of class II and class IV chitinase genes from DF. That said, we have previously reported on an endochitinase-like protein (ECP) in DF that showed a significant upregulation in Phellinus sulphurascens-infected DF plants $(32,54,61,71)$.

In response to pathogen attack, plants generally synthesize two groups of chitinases having either an acidic or basic $\mathrm{p} I$. These two groups of plant chitinases-family 18 and 19 glycosyl hydrolases-use two different hydrolytic mechanisms $(30,57)$. This study confirmed that infected DF seedlings express both acidic and basic chitinase encoding genes which belong to the chitinase family 19 glycosyl hydrolase. The chitinase cDNA sequences and the putative protein sequences that we found showed that there are considerable differences present between these two classes of chitinase genes and proteins and, to a lesser degree, within the two classes. The first 26 or 27 amino acid sequences at the $\mathrm{N}$ terminal ends of these two classes of chitinases are typical of signal peptides, with a highly hydrophobic core and a typical amino acid composition near the cleavage site (69). Within the class IV chitinases, there are eight cysteine residues at identical positions in the chitin-binding region; these residues are necessary for the formation of disulfide bridges that allow the correct folding of domains into a compact active conformation. Class IV chitinases also contain a glycine-rich hinge domain that connects the chitin binding and catalytic domains. It is not yet known if these two chitinase classes have different functional roles; however, our cDNA library results showed that the class II chitinases were smaller and simpler than the class IV chitinases, both in structure and in number. This suggests that DF class IV

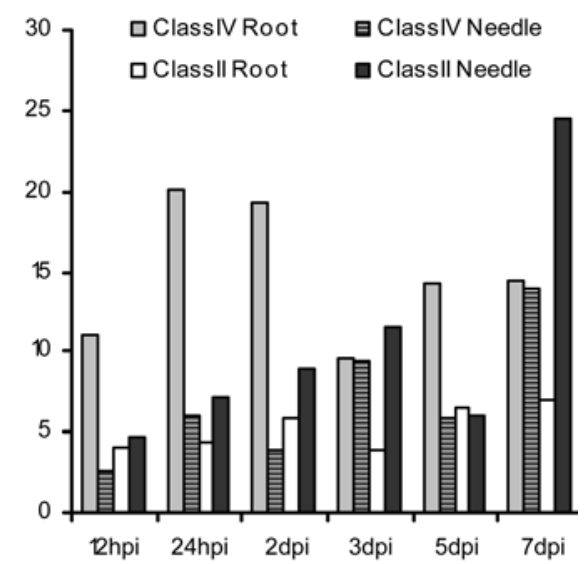

Fig. 4. Cumulative average gene expression (fold changes) of class II and IV chitinase genes in root and needle tissues of Phellinus sulphurascens-infected Douglas-fir (DF) seedlings. Average fold-change values (Y-axis) were calculated based on relative differences of crossing threshold values between control and P. sulphurascens-infected DF samples over different time points of the course of infection (X-axis).

TABLE 2. Gene expression (fold changes) of class II and IV chitinase genes in Phellinus sulphurascens-infected Douglas-fir root and needle tissues over the course of infection ${ }^{\mathrm{a}}$

\begin{tabular}{|c|c|c|c|c|c|c|c|}
\hline \multirow[b]{2}{*}{ Gene ID } & \multirow[b]{2}{*}{ Tissues } & \multicolumn{6}{|c|}{ Fold change over time $(P)^{\mathrm{b}}$} \\
\hline & & 12 hpi & 24 hpi & 2 dpi & 3 dpi & $5 \mathrm{dpi}$ & 7 dpi \\
\hline \multicolumn{8}{|c|}{ Class II (acidic) } \\
\hline Pm Chi2-1 & Root & $2.90(0.50)$ & $3.38(0.30)$ & $7.29(0.00)$ & $3.45(0.02)$ & $9.67(0.00)$ & $7.08(0.00)$ \\
\hline \multirow[t]{2}{*}{ Pm Chi2-2 } & Root & $3.70(0.01)$ & $4.82(0.00)$ & $5.50(0.00)$ & $3.36(0.00)$ & $7.00(0.00)$ & $6.77(0.00)$ \\
\hline & Needle & $10.40(0.01)$ & $9.25(0.24)$ & $9.12(0.04)$ & $7.12(0.00)$ & $4.67(0.05)$ & $22.27(0.00)$ \\
\hline Pm Chi2-3 & Root & $5.70(0.00)$ & $4.91(0.00)$ & $4.73(0.00)$ & $4.78(0.00)$ & $2.64(0.00)$ & $7.25(0.00)$ \\
\hline Pm Chi4-1 & Needle & $2.10(0.68)$ & $5.44(0.15)$ & $2.80(0.20)$ & $11.72(0.00)$ & $2.64(0.19)$ & $13.40(0.00)$ \\
\hline \multirow[t]{2}{*}{ Pm Chi4-2 } & Root & $4.30(0.14)$ & $4.35(0.00)$ & $7.05(0.00)$ & $3.42(0.00)$ & $8.83(0.00)$ & $4.34(0.0)$ \\
\hline & Needle & $2.70(0.61)$ & $7.50(0.24)$ & $3.77(0.02)$ & $7.97(0.00)$ & $5.29(0.00)$ & $11.53(0.00)$ \\
\hline \multirow[t]{2}{*}{ Pm Chi4-3 } & Root & $31.30(0.16)$ & $94.14(0.00)$ & $72.77(0.00)$ & $39.40(0.00)$ & $28.12(0.30)$ & $57.58(0.00)$ \\
\hline & Needle & $1.50(0.90)$ & $8.00(0.43)$ & $4.00(0.59)$ & $8.75(0.01)$ & $5.87(0.11)$ & $23.71(0.00)$ \\
\hline Pm Chi4-4 & Root & $17.40(0.02)$ & $11.79(0.00)$ & $10.22(0.00)$ & $5.56(0.08)$ & $10.35(0.02)$ & $5.97(0.00)$ \\
\hline
\end{tabular}

${ }^{a}$ Fold-change values were obtained from quantitative reverse-transcriptase polymerase chain reaction expression data (crossing threshold values) analyzed by SAS PROC GLM repeated measures analysis of variance. $P$ values obtained from differences between control and $P$. sulphurascens-infected samples.

b Time $=$ hours postinoculation (hpi) and days postinoculation (dpi) 
chitinases may respond differentially and in a more complex manner after pathogen infection than DF class II chitinases. In other plants, basic chitinase-encoding genes have been found to be a complex part of the chitinase gene family, whereas acidic chitinase encoding genes were small in number in the genome $(2,10)$.

Our phylogenetic analyses suggest that class II and IV chitinase genes may have evolved from different phylogenetic lineages, because they are distinct from each other in the phylogenetic tree and do not share a high degree of sequence identity. Our results are supported by other studies, which suggests that (i) chitinase classes I and IV form discrete and well-supported monophyletic classes derived from a common ancestral sequence that predates the divergence of dicots and monocots and (ii) the lack of chitin binding or hinge domains in class II chitinases indicates that they have a polyphyletic origin. Hamel et al. (26) suggest that class II chitinases probably arose from different class I lineages by relatively recent deletion events. In contrast, Liu et al. (40) suggest a common ancestry for the chitinases belonging to the PR-3 family, including class I, II, and IV chitinases, because the position of the first intron of conifer class IV chitinase genes is identical to that of the sole intron of angiosperm class IV chitinase genes, and the positions of two introns of class II and class IV conifer chitinase genes are the same as those of the two introns found in most angiosperm class I and II chitinase genes. Clearly, the evolution of class II and IV chitinase genes in conifer plants is not yet well understood. Nonetheless, the different degrees of chitinase sequence divergence between conifer dicot and monocot species suggests that rapid adaptive evolution may have occurred in chitinases after the divergence of gymnosperms and angiosperms (5).

The present study showed that, regardless of the presence or absence of the nucleotide sequences encoding chitin-binding and hinge domains, expression of both class II and IV chitinase genes was significantly upregulated in Phellinus sulphurascens-infected DF plants, suggesting their important roles in DF defense against the fungus. Despite their phylogenetic and sequence differences, both class II and class IV chitinases have a common catalytic mechanism, as evidenced by the fact that they both contain the putative key catalytic residues in the main catalytic domain (42). The threonine $(\mathrm{T})$ and glutamine $(\mathrm{Q})$ residues play a role in the active site geometry, and the glutamic acid $(\mathrm{E})$ and asparagine $(\mathrm{N})$ residues are important for catalysis $(25,26)$. All these amino acids are present in the catalytic domains of our class II and class IV DF chitinases. There is evidence suggesting that the Cys-rich chitin-binding domain may not be required for antifungal or catalytic activity; however, it is essential for chitin-binding activity (30).

Results of comparisons between average gene expression (fold changes) of class II and IV chitinase genes in DF roots and needles over the course of infection suggest that the two classes may have some degree of spatial and temporal specificity. Class II chitinase genes showed the highest fold changes at 7 dpi and a higher expression in needle tissues while class IV chitinase genes showed higher expression within 24 hpi to 2 dpi and generally more in root tissues (Fig 4). These temporal and spatial expression differences of DF chitinase genes suggest that these two classes of DF chitinases may have a synergistic role in a complex defense system (9). We previously reported that an ECP showed similar trends of temporal and spatial expression after Phellinus sulphurascens infection $(32,54,61,71)$. Expression variations of different chitinase isoforms over time and space were also reported in Heterobasidion annosum- and Rhizoctonia spp.-infected Norway spruce $(20,21,28,44)$. For example, Hietala et al. (28) reported that transcript levels for class II and IV chitinase genes increased at $14 \mathrm{dpi}$ in response to bark colonization by $\mathrm{H}$. anno-

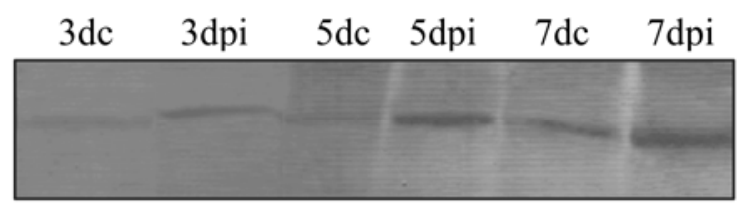

A

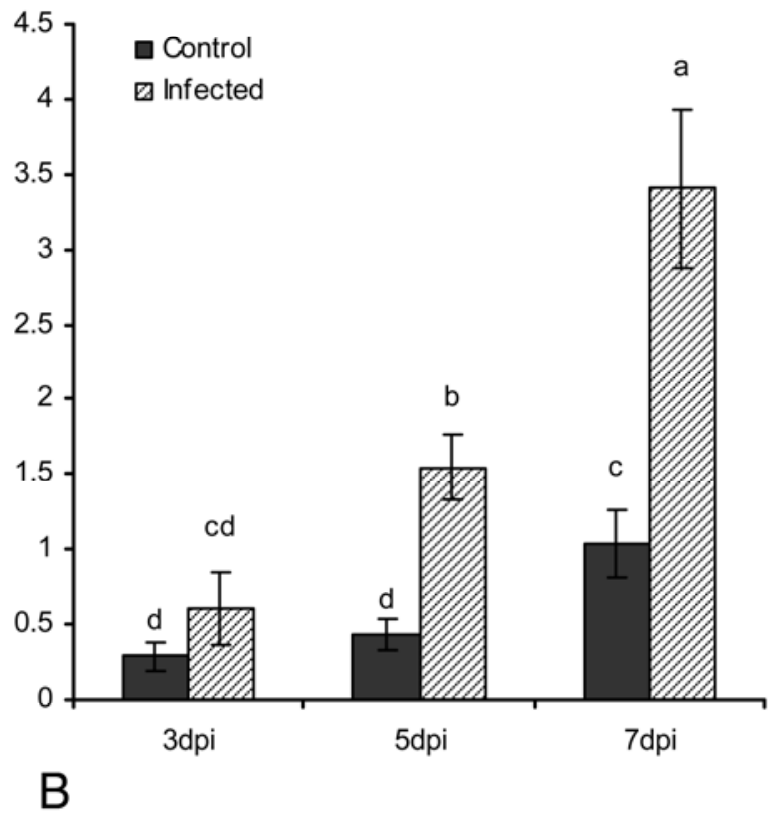

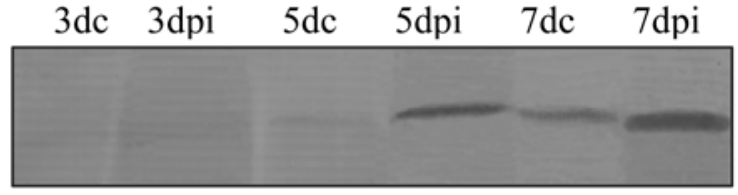

C

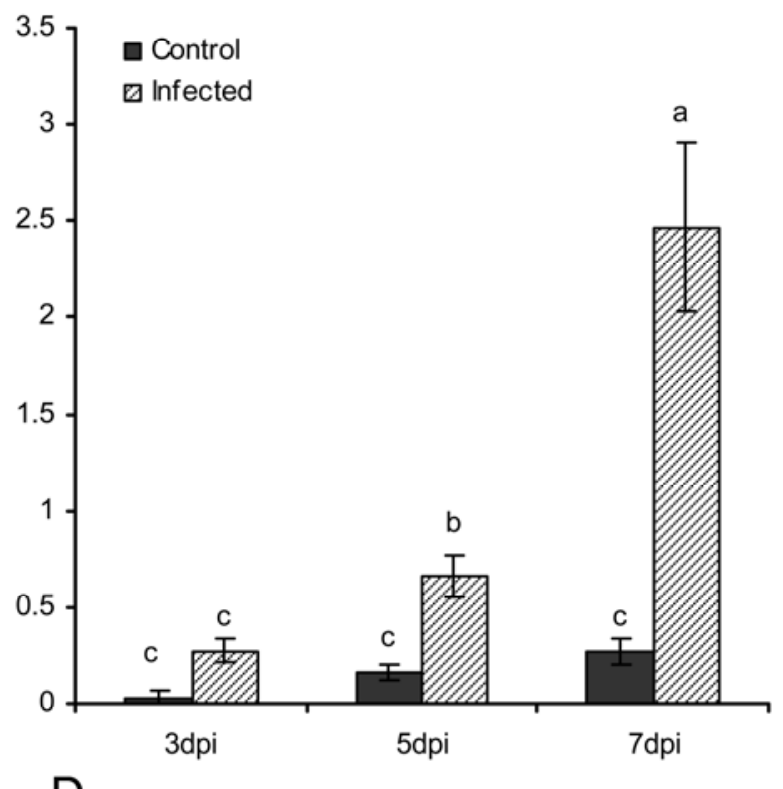

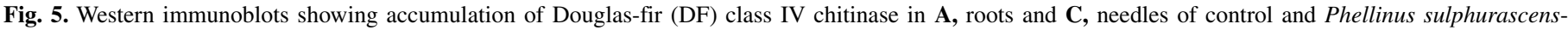

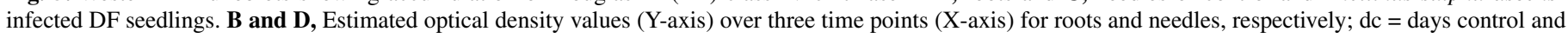
$\mathrm{dpi}=$ days postinoculation. Bars represent the standard error of the means; different letters represent significant differences in the class IV protein accumulation. 
sum in a 32-year-old Norway spruce tree when the fungus was inoculated onto stems $1 \mathrm{~m}$ above the ground level, whereas class I chitinase gene transcript levels declined at the same time point. They also found that transcript levels of the class II and IV chitinase genes were higher in areas immediately adjacent to the inoculation site. We could not compare the expression of class I chitinase genes because we have not identified these genes from DF seedlings. Expression differences for a class IV chitinase have also been reported from Cercospora beticola-infected sugar beet differing in susceptibility to the pathogen-the protein was induced locally in roots but no apparent systemic induction was found and the tolerant sugar beet cultivar accumulated this protein faster than the susceptible one (47).

Western immunoblot results showed that DF class IV chitinases were significantly upregulated in roots as well as in needles of Phellinus sulphurascens-infected seedlings after pathogen challenge. In both root and needle tissues, the highest amount of protein accumulation occurred at $7 \mathrm{dpi}$. Our results also confirmed that protein accumulation in roots was higher in the early stage of infection (i.e., at $3 \mathrm{dpi}$ ) whereas, in needles, protein accumulation was very low or nondetectable early on. These results further support our view that there is some specificity to the expression of DF class IV chitinase genes over time and space. As we stated earlier, the antibody we used shares an antigenic region identical to that of DF class IV chitinases and has $\approx 90 \%$ similarity to the DF class II chitinases. Given this fact and the variation we found in the molecular masses of DF class II (21.85 to $22.59 \mathrm{kDa})$ and class IV (25.11 to $25.78 \mathrm{kDa}$ ) chitinases, we expected two separate bands, corresponding to the class II and class IV DF chitinases, to be evident in our Western immunoblots. However, we observed only a single band and this band most likely corresponded to DF class IV chitinases because the antigenic region of these chitinases is identical to the WWP class IV chitinase antibody. Interestingly, we detected both class II and class IV chitinase isoforms from mature DF root tissues when we ran extracellular proteins in a two-dimensional gel and probed the gel against the WWP class IV chitinase antibody (data not presented). These data suggest that mature DF trees may produce different types of class II chitinases that can be detected by the WWP class IV antibody. These types of class II chitinases might be absent or not detectable in DF seedlings. Another possibility is that the WWP class IV chitinase antibody we used is very specific to DF class IV chitinases. In previous work, we reported an acidic ECP from DF plants, which was significantly upregulated in DF root and needle tissues of plants infected by Phellinus sulphurascens $(32,54,61,71)$ and Armillaria ostoyae $(54)$. The N-terminal amino acid sequence of this acidic ECP showed high homology $(72 \%)$ (data not shown) with DF class II chitinases, suggesting that the reported ECP might be a DF class II chitinase. Interestingly, a recent study (65) showed that a class IV chitinase from Norway spruce has antifungal activity in vitro. This protein shares a high percentage of sequence homology ( 86 to $87 \%$ ) with our DF class IV chitinases, providing further evidence that chitinases likely play important antifungal roles in conifer plants. The specific functions of our differentially expressed DF chitinases remain for us to investigate.

In addition to revealing the presence of chitinases in roots of Phellinus sulphurascens-infected DF seedlings, our cDNA sequence data also showed that such infection induces other major PR genes already reported in planta plus several resistance genes, stress-related genes, and antimicrobial-peptide-encoding genes. Expression profiles completed to date for many of these genes in infected root tissues show variation in expression levels both over time and space and between genes (M. A. Islam, unpublished). These results suggest that DF plants possess a broad-spectrum defense mechanism through multiple biosynthetic signaling pathways $(14,16,21,27,36,49,53,64)$. This type of defense, termed systemic acquired resistance (SAR), results in reduced susceptibility to a second infection in other parts of the plant by the same or even unrelated pathogens $(55,59)$. A SAR event can be rapid and generally involves a massive increase of the defense response $(4,20,21)$, which include three signaling molecules: salicylic acid (SA), jasmonic acid (JA), and ethylene $(14,36,43,53)$. Such defense signaling has been reported to be essential in many conifers $(7,16,21,27,39,50,52)$. There is evidence that conifer chitinases respond differentially to these signal molecules (16). In Arabidopsis, SA and JA levels increase upon pathogen infection and this response activates separate sets of genes encoding PR proteins. For example, the pathogen-inducible genes $P R-1, P R-2$, and $P R-5$ require SA signaling for activation, whereas the plant defensin gene along with $P R-3$ and $P R-4$ genes are induced by pathogens via an SA-independent and JA-dependent pathway (64). It has also been reported that SA induces mainly PR genes coding for acidic PR proteins whereas both ethylene and JA induce mostly the expression of PR genes coding for basic PR isoforms (49). The occurrence of acidic and basic isoforms of chitinase genes in Phellinus sulphurascens-infected DF seedlings suggests that DF chitinases might be activated through a complex system involving more than one signaling pathway. Such complex defense systems provide interesting promise for further research (27).

Our current and previous studies $(32,54,61,71)$ as well as other reports on conifers $(16,20,21,28,40,44)$ strongly suggest that class II and class IV chitinases are major components of conifer defense mechanisms. It is also suggested that, upon infection, DF plants presumably produce structurally different types of chitinases that may differ in localization, antifungal activity, chitinbinding property, and catalytic mechanisms and may vary with plant developmental stages. Due to the different rates of chitinaserelated signal perceptions and transductions that may take place after pathogen attack or wounding, conifer chitinases perform a composite defense response to pathogen attack $(16,20,21,28,44)$. The differential regulation of multiple members of chitinase genes in DF over time and space may provide a greater adaptive capacity in protecting the plant from biotic and abiotic stresses (30). Our future research will include detailed functional studies to confirm antifungal activities of major PR proteins including DF chitinases.

\section{ACKNOWLEDGMENTS}

This work was funded in part by Natural Resources Canada, Canadian Forest Service, Forest Biotechnology/Genomics Initiative funds to R. N. Sturrock. We thank K. Pellow and J.-J. Liu for their technical and scientific support; the British Columbia Ministry of Forests and Range for providing DF seed; and K. Quazi, Associate Director, Quintiles Canada Inc., Quebec, Canada for his assistance with statistical analyses of gene expression data.

\section{LITERATURE CITED}

1. Bairoch, A. 1992. PROSITE: A dictionary of sites and patterns in proteins. Nucleic Acids Res. 20 (Suppl.):2013-2018.

2. Beerhues, L., and Kombrink, E. 1994. Primary structure and expression of mRNAs encoding basic chitinase and 1,3- $\beta$-glucanase in potato. Plant Mol. Biol. 24:353-367.

3. Beintema, J. J. 1994. Structural features of plant chitinases and chitinbinding proteins. FEBS Lett. 350:159-163.

4. Bertini, L., Leonardi, L., Caporale, C., Tucci, M., Cascone, N., Berardino, I. D., Buonocore, V., and Caruso, C. 2003. Pathogen-responsive wheat PR4 genes are induced by activators of systemic acquired resistance and wounding. Plant Sci. 164:1067-1078.

5. Bishop, J. G., Dean, A. M., and Mitchell-Olds, T. 2002. Rapid evolution in plant chitinases: Molecular targets of selection in plant-pathogen coevolution. Proc. Natl. Acad. Sci. USA 97:5322-5327.

6. Bloomberg, W. J., and Reynolds, G. 1985. Growth loss and mortality in laminated root rot infection centers in second-growth Douglas-fir on Vancouver Island. For. Sci. 31:497-508.

7. Bonello, P., Gordon, T. R., Herms, D. A., Wood, D. L., and Erbilgin, N. 
2006. Nature and ecological implications of pathogen-induced systemic resistance in conifers: A novel hypoathesis. Physiol. Mol. Plant. Pathol. 68:97-106.

8. Bowles, D. 1990. Defense related proteins in higher plants. Annu. Rev. Biochem. 59:873-907.

9. Brunner, F., Stintzi, A., Fritig, B., and Legrand, M. 1998. Substrate specificities of tobacco chitinases. Plant J. 14:225-234.

10. Büchter, R., Stromberg, A., Schmelzer, E., and Kombrink, E. 1997. Primary structure and expression of acidic (class II) chitinase in potato. Plant Mol. Biol. 35:749-761.

11. Burdsall, Jr., H. H., and Dorworth, E. B. 1994. Preserving cultures of wood-decaying Basidiomycotina using sterile distilled water in cryovials. Mycologia 86:275-280.

12. Burketová, L., Štillerová, K., and Šindelárová, M. 2003. Immunohistological analysis of chemically induced proteins in sugar beet. Biol. Plant. 47:243-251.

13. Christensen, A. B., Cho, B. H., Næsby, M., Gregersen, P. L., Brandt, J., Madriz-Ordenana, K., Collinge, D. B., and Thordal-Christensen, H. 2002. The molecular characterization of two barley proteins establishes the novel PR-17 family of pathogenesis-related proteins. Mol. Plant Pathol. 3:135-144.

14. Clarke, J. D., Volko, S. M., Ledford, H., Ausubel, F. M., and Dong, X. 2000. Roles of salicylic Acid, jasmonic acid, and ethylene in $c p r$-induced resistance in Arabidopsis. Plant Cell 12:2175-2190.

15. Collinge, D. B., Kragh, K. M., Mikkelsen, J. D., Nielsen, K. K., Rasmussen, J., and Vad, K. 1993. Plant chitinases. Plant J. 3:31-40.

16. Davis, J. M., Wu, H., Cooke, J. E. K., Reed, J. M., Luce, K. S., and Michler, C. H. 2002. Pathogen challenge, salicylic acid, and jasmonic acid regulate expression of chitinase gene homologs in pine. Mol. PlantMicrobe Interact. 15:380-387.

17. Edreva, A. 2005. Pathogenesis-related proteins: Research progress in the last 15 years. Gen. Appl. Plant Physiol. 31:105-124.

18. Eijsink, V. G. H., Vaaje-Kolstad, G., Vårum, K. M., and Horn, S. J. 2008. Towards new enzymes for biofuels: Lessons from chitinase research. Trends Biotechnol. 26:228-235.

19. Ekramoddoullah, A. K. M., and Davidson, J. J. 1995. A method for the determination of foliage protein extracted using sodium dodecyl sulphate and mercaptoethanol. Phytochem. Anal. 6:20-24.

20. Fossdal, C. G., Hietala, A. M., Kvaalen, H., and Solheim, H. 2006. Changes in host chitinase isoforms in relation to wounding and colonization by Heterobasidion annosum: Early and strong defense response in 33-year-old resistant Norway spruce clone. Tree Physiol. 26:169-177.

21. Fossdal, C. G., Nagy, N. E., Johnsen, Ø., and Dalen, L. S. 2007. Local and systematic stress responses in Norway spruce: Similarities in gene expression between a compatible pathogen interaction and drought stress. Physiol. Mol. Plant Pathol. 70:161-173.

22. Frettinger, P., Herrmann, S., Lapeyrie, F., Oelmüller, R., and Buscot, F. 2006. Differential expression of two class III chitinases in two types of roots of Quercus robur during pre-mycorrhizal interactions with Piloderma croceum. Mycorrhiza 16:219-223.

23. Fujita, M., Fujita, Y., Noutoshi, Y., Takahashi, F., Narusaka, Y., Yamaguchi-Shinozaki, K., and Shinozaki, K. 2006. Crosstalk between abiotic and biotic stress responses: A current view from the points of convergence in the stress signaling networks. Curr. Opin. Plant Biol. 9:436-442.

24. Gerhardt, L. B. A., Sachetto-Martins, G., Contarini, M. G., Sandroni, M., Ferreira, R. P., Lima, V. M., Cordeiro, M. C., Oliveira, D., and MargisPinheiro, M. 1997. Arabidopsis thaliana class IV chitinase is early induced during the interaction with Xanthomonas campestris. FEBS Lett. 419:69-75.

25. Graham, L. S., and Sticklen, M. B. 1994. Plant chitinases. Can. J. Bot. 72:1057-1083.

26. Hamel, F., Boivin, R., Tremblay, C., and Bellemare, G. 1997. Structural and evolutionary relationships among chitinases of flowering plants. J. Mol. Evol. 44:614-624.

27. Hammerschmidt, R. 2006. Host-pathogen interaction in conifers: Complicated systems yield interesting possibilities for research. Physiol. Mol. Plant Pathol. 68:93-94.

28. Hietala, A. M., Kvaalen, H., Schmidt, A., Johnk, N., Solheim, H., and Fossdal. C.G. 2004. Temporal and spatial profiles of chitinase expression by Norway spruce in response to bark colonization by Heterobasidion annosum. Appl. Environ. Microbiol. 70:3948-3953.

29. Hodge, A., Alexander, I. J., and Gooday, G. W. 1995. Chitinolytic activities of Eucalyptus pilularis and Pinus sylvestris root systems challenged with mycorrhizal and pathogenic fungi. New Phytol. 131:255261.

30. Iseli, B., Armand, S., Boller, T., Neuhaus, J.-M., and Henrissat, B. 1996. Plant chitinases use two different hydrolytic mechanisms. FEBS Lett. 382:186-188.
31. Islam, M. A., Sturrock, R. N., and Ekramoddoullah, A. K. M. 2008. A proteomics approach to identify proteins differentially expressed in Douglas-fir seedlings infected by Phellinus sulphurascens. J. Proteom. 71:425-438.

32. Islam, M. A., Sturrock, R. N., Holmes, T. A., and Ekramoddoullah, A. K. M. 2009. Ultrastructural studies of Phellinus sulphurascens infection of Douglas-fir roots and immunolocalization of host pathogenesis-related proteins. Mycol. Res. 113:700-712.

33. Kasprzewska, A. 2003. Plant chitinases-regulation and function. Cell. Mol. Biol. Lett. 8:809-824.

34. Kim, H. B., and An, C. S. 2002. Differential expression patterns of an acidic chitinase and a basic chitinase in the root nodule of Elaeagnus umbellate. Mol. Plant-Microbe Interact. 5:209-215.

35. Koga, D. 2005. Application of chitinases in agriculture. J. Min. Met. Mats. 15:33-35.

36. Kunkel, B. N., and Brooks, D. M. 2002. Cross talk between signaling pathways in pathogen defense. Curr. Opin. Plant. Biol. 5:325-331.

37. Larsen, M. J., Lombard, F. F., and Clark, J. W. 1994. Phellinus sulphurascens and the closely related $P$. weirii in North America. Mycologia 86:121-130.

38. Legrand, M., Kauffmann, S., Geoffroy, P., and Fritig, B. 1987. Biological function of pathogenesis-related proteins: Four tobacco pathogenesisrelated proteins are chitinases. Proc. Natl. Acad. Sci. USA 84:6750-6754.

39. Liu, J. J., Ekramoddoullah, A. K. M., and Yu, X. 2003. Differential expression of multiple PR10 proteins in western white pine following wounding, fungal infection and cold-hardening. Physiol. Plant. 119:544553.

40. Liu, J.-J., Ekramoddoullah, A. K. M., and Zamani, A. 2005. A class IV Chitinase is upregulated by fungal infection and abiotic stresses and associated with slow-canker growth resistance to Cronartium ribicola in Western White Pine (Pinus monticola). Phytopathology 95:284-291.

41. Meins, F., Jr., Fritig, B., Linthorst, H. J. M., Mikkelsen, J. D., Neuhaus, J.M., and Ryals, J. 1994. Plant chitinase genes. Plant Mol. Biol. Rep. 12:S22-S28.

42. Mitsunaga, T., Iwase, M., Ubhayasekera, W., Mowbray, S. L., and Koga, D. 2004. Molecular cloning of a genomic DNA encoding yam class IV chitinase. Biosci. Biotech. Biochem. 68:1508-1517.

43. Mur, L. A. J., Kenton, P., Atzorn, R., Miersch, O., and Wasternack, C. 2006. The Outcomes of concentration-specific interactions between salicylate and jasmonate signaling include synergy, antagonism, and oxidative stress leading to cell death. Plant Physiol. 140:249-262.

44. Nagy, N. E., Fossdal, C. G., Dalen, L. S., Lönneborg, A., Heldal, I., and Johnsen, Ø. 2004. Effects of Rhizoctonia infection and drought on peroxidase and chitinase activity in Norway spruce (Picea abies). Physiol. Plant. 120:465-473.

45. Nelson, E. E., and Sturrock, R. N. 1993. Susceptibility of western conifers to laminated root rot (Phellinus weirii) in Oregon and British Columbia field tests. West. J. Appl. For. 8:67-70.

46. Neuhaus, J.-M., Fritig, B., Linthorst, H. J. M., Meins, F., Jr., Mikkelsen, J. D., and Ryals, J. 1996. A revised nomenclature for chitinase genes. Plant Mol. Biol. Rep. 14:102-104.

47. Nielsen, J. E., Nielsen, K. K., and Mikkelsen, J. D. 1996. Immunohistological localization of a basic class IV chitinase in Beta vulgaris leaves after infection with Cercospora beticola. Plant Sci. 119:191-202.

48. Pfaffl, M. W. 2001. A new mathematical model for relative quantification in real-time RT-PCR. Nucleic Acids Res. 29:2002-2007.

49. Pieterse, C. M. J., and van Loon, L. C. 1999. Salicylic acid-independent plant defence pathways. Trends Plant Sci. 4:52-58.

50. Piggott, N., Ekramoddoullah, A. K. M., Liu, J.-J., and Yu, X. 2004. Gene cloning of a thaumatin-like (PR-5) protein of western white pine (Pinus monticola D. Don) and expression studies of members of the PR-5 group. Physiol. Mol. Plant Pathol. 64:1-8.

51. Quecine, M. C., Araujo, W. L., Marcon, J., Gai, C. S., Azevedo, J. L., and Pizzirani-Kleiner, A. A. 2008. Chitinolytic activity of endophytic Streptomyces and potential for biocontrol. Lett. Appl. Microbiol. 47:486491.

52. Ralph, S. G., Yueh, H., Friedmann, M., Aeschliman, D., Zeznik, J. A., Nelson, C. C., Butterfield, Y. S. N., Kirkpatrick, R., Liu, J., Jones, S. J. M., Marra, M. A., Douglas, C. J., Ritland, K., and Bohlmann J. Conifer defence against insects: Microarray gene expression profiling of Sitka spruce (Picea sitchensis) induced by mechanical wounding or feeding by spruce budworms (Choristoneura occidentalis) or white pine weevils (Pissodes strobi ) reveals large-scale changes of the host transcriptome. Plant Cell Environ. 29:1545-1570.

53. Reymond, P., and Farmer, E. E. 1998. Jasmonate and salicylate as global signals for defense gene expression. Curr. Opin. Plant Biol. 1:404-411.

54. Robinson, R. M., Sturrock, R. N., Davidson, J. J., Ekramoddoullah A. K. M., and Morrison, D. J. 2000. Detection of chitinase-like protein in the roots of Douglas-fir trees infected with Armillaria ostoyae and Phellinus weirii. Tree Physiol. 20:493-502. 
55. Ryals, J. A., Neuenschwander, U. H., Willits, M. G., Molina, A., Steiner, H.-Y., and Hunt, M. D. 1996. Systemic acquired resistance. Plant Cell 8:1808-1819.

56. Schultz, D. J., Craig, R., Cox-Foster, D. L., Mumma, R. O., and Medford, J. O. 1994. RNA isolation from recalcitrant plant tissue. Plant Mol. Biol. Rep. 12:310-316.

57. Sekeli, R., Wan, Y. T. Y., Kulaveerasingam, H., Napis, S., and Hee, T. S. 2003. The isolation and expression analysis of a class I chitinase from developing winged bean seed (Psophocarpus tetragonolubus). Asia-Pac. J. Mol. Biol. Biotechnol. 11:63-69.

58. Selitrennikoff, C. P. 2001. Antifungal proteins. Appl. Environ. Microbiol. 67:2883-2894.

59. Sticher, L., Mauch-Mani, B., and Métraux, J.-P. 1997. Systemic acquired resistance. Annu. Rev. Phytopathol. 35:235-270.

60. Stintzi, A., Heitz, T., Prasad, V., Widemann-Merdinoglu, S., Kauffmann, S., Geoffroy, P., Legrand, M., and Fritig, B. 1993. Plant 'pathogenesis related' proteins and their role in defense against pathogens. Biochemie 75:687-706.

61. Sturrock, R. N., Islam, M. A., and Ekramoddoullah, A. K. M. 2007. Hostpathogen interactions in Douglas-fir seedlings infected by Phellinus sulphurascens. Phytopathology 97:1406-1414.

62. Tamura, K., Dudley, J., Nei, M., and Kumar, S. 2007. MEGA 4: Molecular Evolutionary Genetics Analysis (MEGA) software version 4.0. Mol. Biol. Evol. 24:1596-1599.

63. Thies, W. G., and Sturrock, R. N. 1995. Laminated root rot in western North America. Gen. Tech. Rep. PNW-GTR-349, U.S. Dep. Agric. Portland, OR.

64. Thomma, B. P. H. J., Eggermont, K., Penninckx, I. A. M. A., Mauch-
Mani, B., Vogelsang, R., Cammue, B. P. A., and Broekaert, W. F. 1998. Separate jasmonate-dependent and salicylate-dependent defense-response pathways in Arabidopsis are essential for resistance to distinct microbial pathogens. Proc. Natl. Acad. Sci. USA 95:15107-15111.

65. Ubhayasekera, W., Rawat, R., Ho, S. W. T., Wiweger, M., Von Arnold, S., Chye, M.-L., and Mowbray, S. L. 2009. The first crystal structures of a family 19 class IV chitinase: The enzyme from Norway spruce. Plant Mol. Biol. 71:277-289.

66. van Loon L. C., Rep, M., and Pieterse, C. M. J. 2006. Significance of inducible defence-related proteins in infected plants. Annu. Rev. Phytopathol. 44:135-162.

67. van Loon, L. C., and van Strien, E. A. 1999. The families of pathogenesisrelated proteins, their activities, and comparative analysis of PR-1 type proteins. Physiol. Mol. Plant. Pathol. 55:85-97.

68. Verburg, J. G., Rangwala, S. H., Samac, D. A., Luckow, V. A., and Huynh, Q. K. 1993. Examination of the role of tyrosine-174 in the catalytic mechanism of the Arabidopsis thaliana chitinase: Comparison of variant chitinases generated by site-directed mutagenesis and expressed in insect cells using baculovirus vectors. Arch. Biochem. Biophys. 300: 223-230.

69. von Heijne, G. 1983. Pattern of amino acids near signal-sequence cleavage sites. Eur. J. Biochem. 133:17-21.

70. Wessels, J. G. H. 1994. Developmental regulation of fungal cell wall formation. Annu. Rev. Phytopathol. 32:413-437.

71. Zamani, A., Sturrock, R. N., Ekramoddoullah, A. K. M., Wiseman, S. B., and Griffith, M. 2003. Endochitinase activity in the apoplastic fluid of Phellinus weirii-infected Douglas-fir and its association with over wintering and antifreeze activity. For. Pathol. 33:299-316. 